\title{
Toxic cyanobacteria strains isolated from blooms in the Guadiana River (southwestern Spain)
}

\author{
ISABEL M. MORENO ${ }^{1}$, PAULO PEREIRA $^{2}$, SUSANA FRANCA $^{2}$ and ANA CAMEÁN ${ }^{1}$
}

\author{
1 Área de Toxicología, Facultad de Farmacia, Universidad de Sevilla, c/o Profesor García González \\ No 2, 41012-Sevilla, Spain \\ ${ }^{2}$ Laboratorio de Microbiologia e Ecotoxicologia. Instituto da Saúde Ricardo Jorge. \\ Avda. Padre Cruz 1649-016, Lisboa, Portugal
}

\begin{abstract}
This paper describes the occurrence of toxic cyanobacteria along the Guadiana River over its course between Mérida and Badajoz (Extremadura, Spain). Water sampling for phytoplankton quantification and toxin analysis was carried out regularly between 1999 and 2001 in six different locations, including two shallow, slow-flowing river sites, two streamed river sites and two drinking water reservoirs. The cyanobacterial community differed significantly between these locations, especially during the summer. The predominant genera were Microcystis, Oscillatoria, Aphanizomenon and Anabaena. Using an ELISA assay the total microcystin contents of natural water samples from the most eutrophic locations ranged from $0.10-21.86 \mu \mathrm{g}$ mcyst-LR equivalent $\cdot \mathrm{L}^{-1}$ in Valdelacalzada and $0.10-11.3 \mu \mathrm{g}$ mcyst-LR equivalent $\cdot \mathrm{L}^{-1}$ in Vitonogales, and a seasonal variation of toxin content was observed. The amount of microcystins produced by each strain was determined by ELISA assay and the detection and identification of microcystin variants of three toxic strains of Microcystis aeruginosa was performed by high performance liquid chromatography (HPLC). The analysis of microcystins of the cultured strains revealed that toxin production was variable among different strains of M. aeruginosa isolated either from different blooms or from the same bloom.
\end{abstract}

Key terms: Cyanobacteria, microcystins, Guadiana, Spain

\section{INTRODUCTION}

The frequency, intensity, and geographic distribution of toxic episodes in the aquatic environment seem to be increasing in recent decades due to the proliferation of harmful algae (Gago-Martínez et al. 2003). One of the major problems arising from harmful algae blooms is the production of toxins (Rivas et al. 2000; García et al. 2003). Cyanobacteria, also called blue-green algae, are common and natural phytoplankton components in most freshwater ecosystems. However, their massive proliferations, often caused by the high nutrient loadings resulting from fertilizer run-off and livestock, industrial, and human wastes, may have a detrimental effect on both the ecosystem and terrestrial animals, including humans (Bartram et al. 1999). The hepatotoxic microcystins (mcyst) are amongst the most frequently reported cyanotoxins (Sivonen and Jones 1999), as they are not only associated with Microcystis blooms, but also with blooms of Anabaena, Hapalosiphon, Nostoc and Oscillatoria (Brittain et al. 2000). These compounds represent, by different exposure routes, a significant health hazard to humans and livestock (Kuiper-Goodman et al. 1999), being involved in several intoxication episodes throughout the world, and even in death of humans exposed through haemodialysis (Jochimsen et al. 1998). The observed hepatotoxicity of microcystins is based on their specific inhibition of protein phosphatase 1 and $2 \mathrm{~A}$ in liver cells, leading to acute liver failure via disruption of

Corresponding author: Ana Cameán, Área de Toxicología, Facultad de Farmacia, Universidad de Seville, c/o Profesor García González № 2, 41012-Sevilla, España. Telephone: (34-95) 455-6762. Fax: (34-95) 423-3765.

E-mail: camean@us.es

Received: March 1, 2004. In Revised Form: April 26, 2004. Accepted: April 30, 2004. 
hepatocyte cytoskeletal components (Fastner et al. 1999). Furthermore, microcystins have been shown to act as tumor promoters (Nishiwaki-Matsushima et al. 1992) and have been considered as a major risk factor contributing to the high rate of hepatocellular carcinoma in south-east China (Ueno et al. 1996).

Although in recent years, toxic cyanobacterial blooms have been reported with an increasing frequency in different countries worldwide, often associated with the production of microcystins, such toxic occurrences are poorly documented in Spain. Most work has been done in the field of water bloom ecology (Quesada et al. 1998; Garcia-Pichel and Pringault 2001) and taxonomy (López-Rodas and Costas 1997; Abed et al. 2002), although some authors have recently developed new analytical methods to determine these toxins in Spanish and Portuguese waters (Barco et al. 2002; Aguete et al. 2003; Gago-Martínez et al. 2003). This is particularly striking given that toxic cyanobacterial blooms are very common events in Portugal, particularly in some of the transnational rivers that flow from Spain (Ferreira et al. 2001; Vasconcelos, 1993; Rocha et al. 2002).

The Guadiana River $(810 \mathrm{~km})$, located in the southwestern part of the Iberian Peninsula, is one of these trans-boundering rivers used for different purposes, including agriculture, drinking water, and recreation. In fact, the Guadiana Valley is characterized by its great fertility, dominated by the vast irrigated land, and with an exceptional emphasis on agriculture. The river is one of the most important, although highly eutrophic, sources of fresh water in both the arid area of Extremadura, Spain, and the dry region of southern Portugal. In the summer period the river-flow usually decreases significantly, and the volume of water in the several dams constructed along its course through Spain and Portugal drops considerably. Blooms of cyanobacteria, generally dominated by the potentially toxic Microcystis spp. have been frequently reported in the Guadiana River, along its downstream course through the Portuguese territory (Vasconcelos et al. 1996; Pereira et al. 1999, Rocha et al. 2002). However, little is known about the phytoplankton communities and associated toxicities occurring upstream, i.e., along the river's course from Mérida to Badajoz (Extremadura, Spain). This is important not only to identify the most problematic sites for cyanobacteria proliferation in the Guadiana River in its Spanish course through Extremadura, but also to elucidate the origin and the causes for the frequent bloom occurrences detected downstream.

This paper reports the first screening of cyanobacterial blooms and associated toxins in the Spanish portion of the Guadiana River, done during the summer periods of 1999-2001.

\section{MATERIAL AND METHODS}

\section{Sample Collection}

Water samples (2 L) were collected between June and December of 1999, 2000, and 2001 from the surface near the shore of the Guadiana River along its course between Mérida and Badajoz. Six sampling sites were selected in order to include two different shallow slow-flowing river sites (Vitonogales and Valdelacalzada), two well-streamed river sites (Barbaño and Pescadores) and two water dams used for agricultural, recreational, and drinking purposes (Alange and Montijo). These locations are shown in Figure 1. The samples were stored and transported to the laboratory in an ice chest.

\section{Phytoplankton identification and quantification}

Subsamples (100 $\mathrm{mL})$ were preserved in lugol solution and observed under an inverted microscope using 5-25 mL sedimentation chambers for phytoplankton identification and quantification (Utermöhl 1958). Cyanobacterial genera and species were identified by microscopic observation of distinguishing morphological characters cited in the literature (Baker 1991, 1992; Komarek and Anagnostidis 1986). 


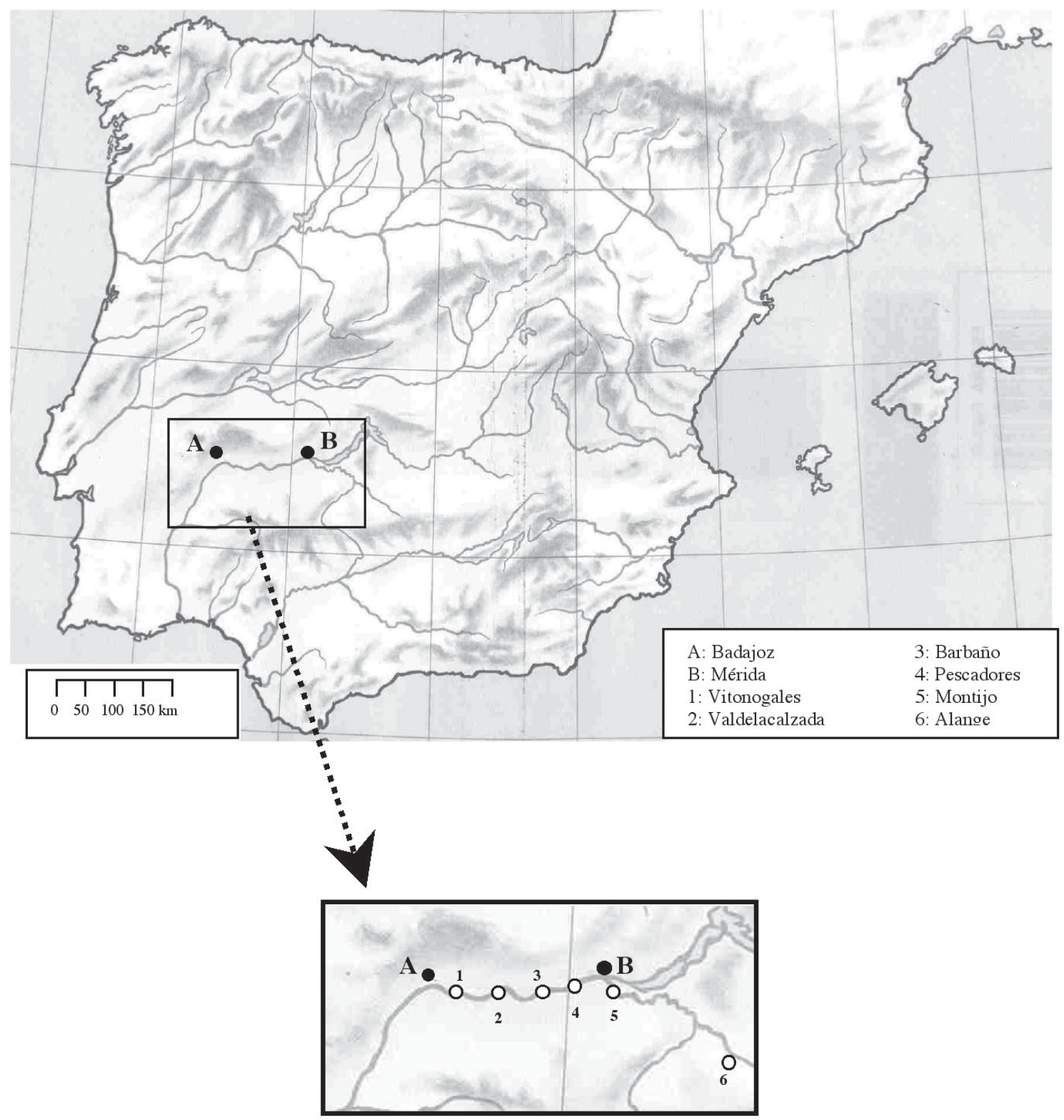

Figure 1. Map and location of Guadiana River and its reservoirs.

\section{Cyanobacterial cultures}

Fourteen different strains were isolated from the natural water samples under the microscope using a sterilized Pasteur pipette to collect single cells or small colonies from a small drop of the water sample. These rough isolates, with little surrounding medium, were rinsed in several drops of sterilized Z8 medium (Skulberg and Skulberg 1990) to remove the contaminating cells and suspended particles.
For the isolation and characterization of microcystins only three Microcystis aeruginosa strains (two from a 1999 bloom sample located in Vitonogales and one from 2000 bloom from Valdelacazada) isolated were used. Each single cell or colony was transferred to a $250 \mathrm{~mL}$ sterilized glass Erlenmeyers containing $100 \mathrm{~mL}$ of $\mathrm{Z} 8$ medium and maintained at $20 \pm 1^{\circ} \mathrm{C}$ with a $16 / 8 \mathrm{~h} \mathrm{~L} / \mathrm{D}$ cycle (light intensity $30 \mu \mathrm{E} \mathrm{m} \mathrm{m}^{-2}$ $\left.\mathrm{s}^{-1}\right)$. Stock cultures were obtained by transferring $1 \mathrm{~mL}$ of these start cultures as 
an inoculum to new $\mathrm{Z} 8$ medium $(100 \mathrm{~mL})$. $10 \mathrm{~mL}$ of each stock culture were used as inoculum (initial concentration of $2-5 \cdot 10^{3}$ cells $\cdot \mathrm{mL}^{-1}$ ) for mass cultivation in $4 \mathrm{~L} \mathrm{Z8}$ medium bulks. These were maintained with constant air supply under the light and temperature conditions described above. Aliquots were taken once a week and preserved in lugol solution for cell counting; other aliquots were also taken for toxin determination by ELISA assay (see toxin determination). Cultures were harvested at mid- to late-exponential phases and concentrated by centrifugation or decantation under natural light. The concentrated algae material was preserved at $-20^{\circ} \mathrm{C}$ until lyophilization.

\section{Toxin determination}

The determination of microcystins in both the natural water samples and in the cultured strains was first done using a commercially available competitive ELISA kit for the determination of microcystins in water (Envirogard ${ }^{\circledR}$, Strategic Diagnostic INC, Newark, USA). This assay uses antibodies against microcystin-LR, the most common microcystin, and detects the presence of other microcystin variants to differing degrees. Samples from natural waters and isolated strains treated twice by freeze thawing followed by filtration over non-sterile $0.45 \mu \mathrm{m}$ filter (Millex HV13, Millipore, USA), were diluted to fall within the range of the kit standards $(0.1$ to $1.6 \mu \mathrm{g}$ microcystin-LR equivalent $\mathrm{L}^{-1}$ ) and added in duplicate to the 96 -well microtiter plate. Spectrophotometric measurements were performed at $450 \mathrm{~nm}$.

Further identification and quantification of microcystins variants in the cultured strains was done by HPLC-UV. Extraction of microcystins from the lyophilized culture material was done according to the method of Lagos et al. (1999) with slight modifications. The cells $(50 \mathrm{mg})$ were extracted with one volume $(10 \mathrm{~mL})$ of 0.1 $\mathrm{M}$ acetic acid and two volumes $(20 \mathrm{~mL})$ of methanol:chloroform $(1: 1 \mathrm{v} / \mathrm{v})$ solution. After sonication in an ultra-sound bath for 15 minutes and stirring for 30 minutes at room temperature, the cell suspensions were centrifuged. For a quantitative extraction of the toxins, this procedure was performed three times. Supernatants were combined and concentrated in a Speed-Vac. The toxin-containing fractions were eluted in $0.5 \mathrm{~mL}$ of methanol. The resulting extracts were immediately used for analysis or preserved at $-20^{\circ} \mathrm{C}$ until used. HPLC-UV analysis was carried out on a Varian liquid chromatograph (Varian, Walnut Creek, USA) equipped with a 9012 pump and a 9050 UV-Visible spectrophotometric detector. Chromatographic data were processed with Star Chromatography Workstation (version 4.5 Varian Associates Inc, Walnut Creek, USA) software. Analytical separations were performed under reversed-phase isocratic conditions with a $\mathrm{C} 18$ reversed phase column $(5 \mu \mathrm{m}$, 250x4 mm, LiChrospher ${ }^{\circledR} 100$, Merck, Darmstadt, Germany). The mobile phase consisted of $65 \% 5 \mathrm{~m} M$ phosphate buffer ( $\mathrm{pH} 2.8$ adjusted with phosphoric acid) and $35 \%$ acetonitrile (Cameán et al. 1997). The wavelength was set at $238 \mathrm{~nm}$ and the flow rate was $1 \mathrm{~mL} \cdot \mathrm{min}^{-1}$. Sample injection volumes were typically $20 \mu \mathrm{L}$. All solvents and chemicals were of HPLC grade or analytical grade. Distilled, deionized water (Milli-Q Water Systems, Millipore Corporation, Bedford, MA, USA) was used to prepare all aqueous solutions. Microcystin-LR (mcyst-LR), mcyst-RR and mcyst-YR standards were purchased from Calbiochem-Novabiochem (Nottingham, UK). Standard solutions were prepared in methanol $\left(500 \mu \mathrm{g} \cdot \mathrm{mL}^{-1}\right)$ and were diluted as required with methanol for use as working solutions $\left(0.5-5.0 \mathrm{mg} \cdot \mathrm{L}^{-1}\right.$ of each toxin).

\section{RESULTS}

Cyanobacteria community and potential toxicity

Figure 2(A-F) shows the relative abundance of cyanobacteria compared with other groups of phytoplankton (such as diatoms and chlorophytes) found in each of the six sampling sites, during the summer periods of 1999, 2000, and 2001. In all locations, the dominant species were cyanobacteria, with a 
(a)

-CYANOBACTERIA $\square$ CHLOROPHYTES $\square$ DIATOMS

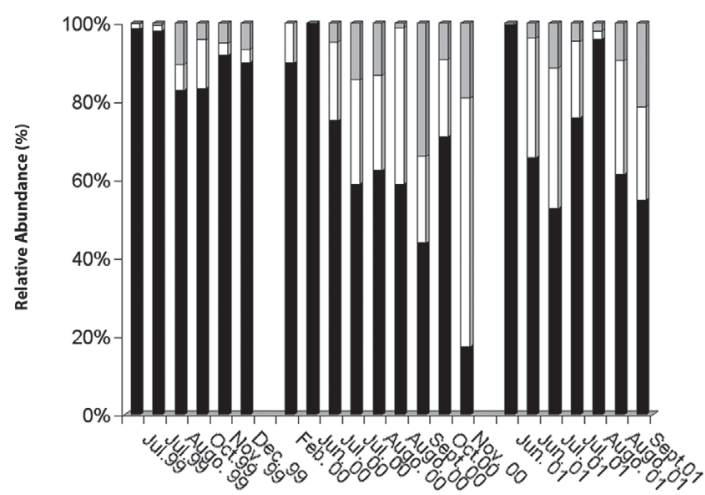

(b)

- CYANOBACTERIA $\square$ CHLOROPHYTES $\square$ DIATOMS

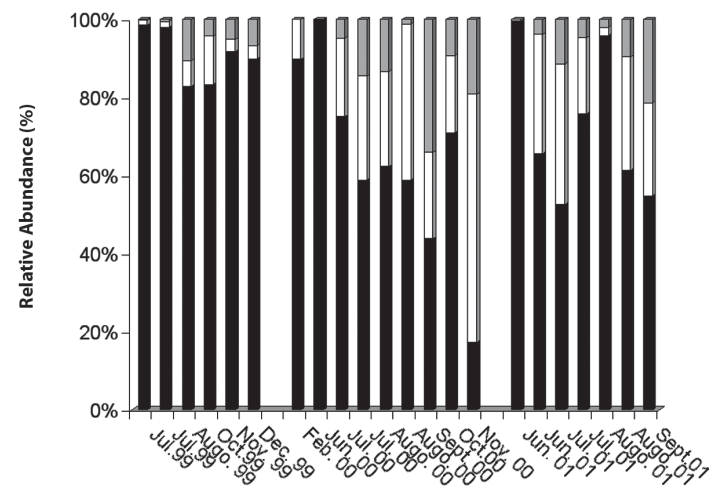

(c)

- CYANOBACTERIA $\square$ CHLOROPHYTES $\square$ DIATOMS

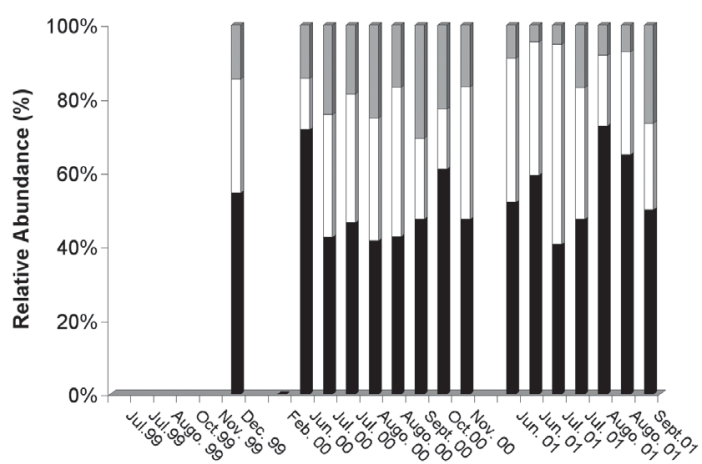

(d)

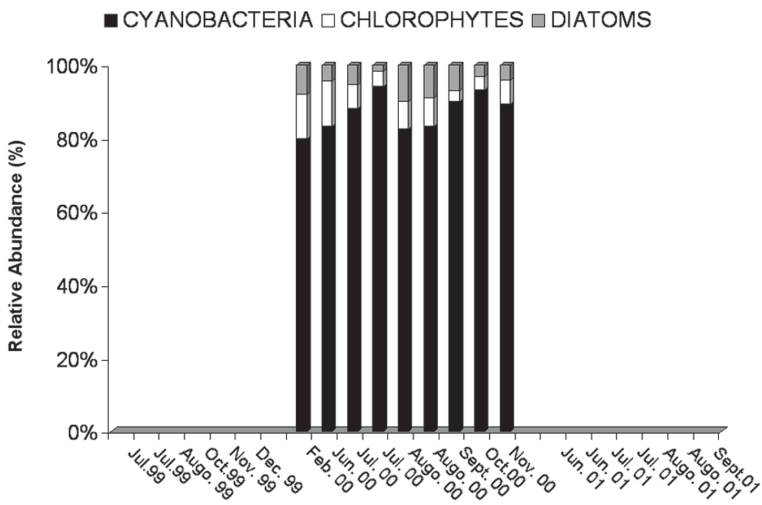

(e)

- CYANOBACTERIA $\square$ CHLOROPHYTES $\square$ DIATOMS

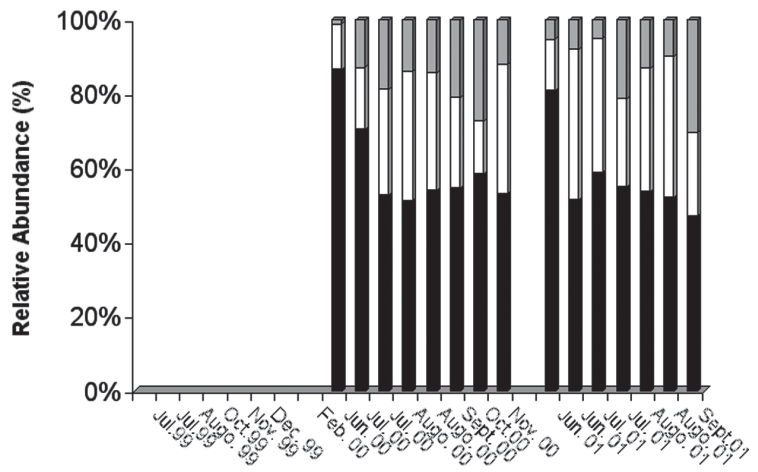

(f)

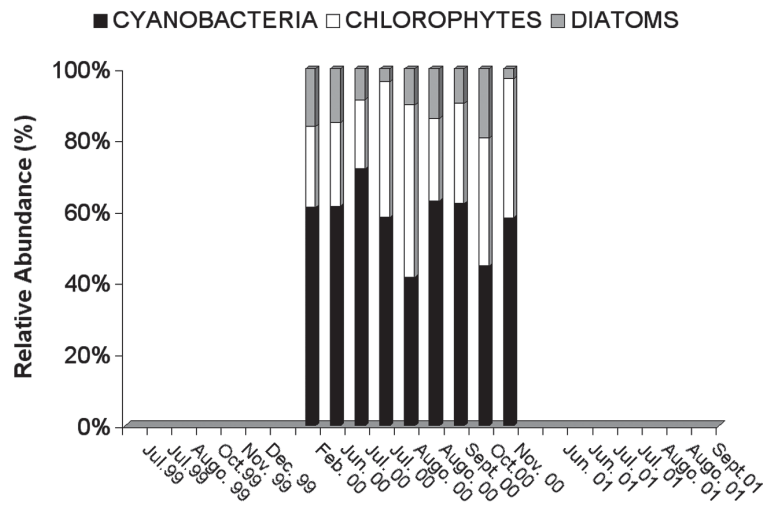

Figure 2. Relative abundance of total cyanobacteria compared with chlorophytes and diatoms detected in (a) Valdelacalzada (b) Vitonogales (c) Montijo (d) Alange (e) Pescadores and (f) Barbaño in the sampling period. 
relative abundance range between 50-95 \%. Microcystis aeruginosa, Aphanizomenon spp, Oscillatoria spp. and some species of the genera Anabaena, such as $A$. spiroides and $A$. inaequalis were the predominant species detected in the Guadiana River. A high incidence of cyanobacterial blooms was found in two of the six locations studied, namely in Valdelacalzada and in Vitonogales, the two shallow and slow-flowing river sampled sites (Figs 2A and 2B, respectively). Cyanobacteria cell density in the blooms ranged from $10^{6}-1.4 \times 10^{7}$ and $3 \times 10^{5}-3 \times 10^{6}$ cells $\mathrm{mL}^{-1}$ in Valdelacazada and Vitonogales, respectively. On the other hand, the cyanobacteria densities were always much lower in the river reservoirs Montijo and Alange (Figs 2C and 2D, respectively), with maximum concentrations of cyanobacteria of $31 \times 10^{3}$ and $2.4 \times 10^{2}$ cells $\mathrm{mL}^{-1}$. The two wellstreamed portions Barbaño and Pescadores presented an intermediate situation $\left(5 \times 10^{4}\right.$ and $15 \times 10^{4}$ cells $\mathrm{mL}^{-1}$ ) where cyanobacteria were the predominant organisms within the phytoplankton community but never formed massive bloom proliferations (Figs $2 \mathrm{E}$ and $2 \mathrm{~F}$, respectively).

(a)

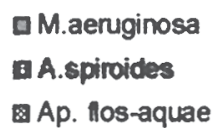

口 Oscillatoria spp.

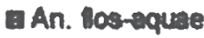

A. issatchenkoi
Although showing significant differences in terms of cell densities, the blooms detected simultaneously in Valdelacalzada and Vitonogales showed great similarities in terms of species composition (Figs 3A and 3B). Whereas in July 1999 the blooms were composed mainly of Microcystis aeruginosa, Aphanizomenon flos-aquae, Anabaena spiroides and Oscillatoria spp, two years later, in June 2001, the blooms detected in both sites were mainly formed of $M$. aeruginosa. On the other hand, the occurrence of mass proliferations was not always coincident in both sites. Whereas in Valdelacalzada a massive bloom composed of $M$. aeruginosa and Oscillatoria spp. occurred in June 2000, at Vitogonales the only cyanobacterial bloom detected that year occurred 4 months latter and was dominated by $M$. aeruginosa.

Seasonal variations of microcystin contents (ELISA analysis) in natural waters from Vitonogales and Valdelacalzada were shown in Figure 3. In both cases peaks in toxin content were recorded during midsummer periods and coincide with peaks of cyanobacterial biomass.

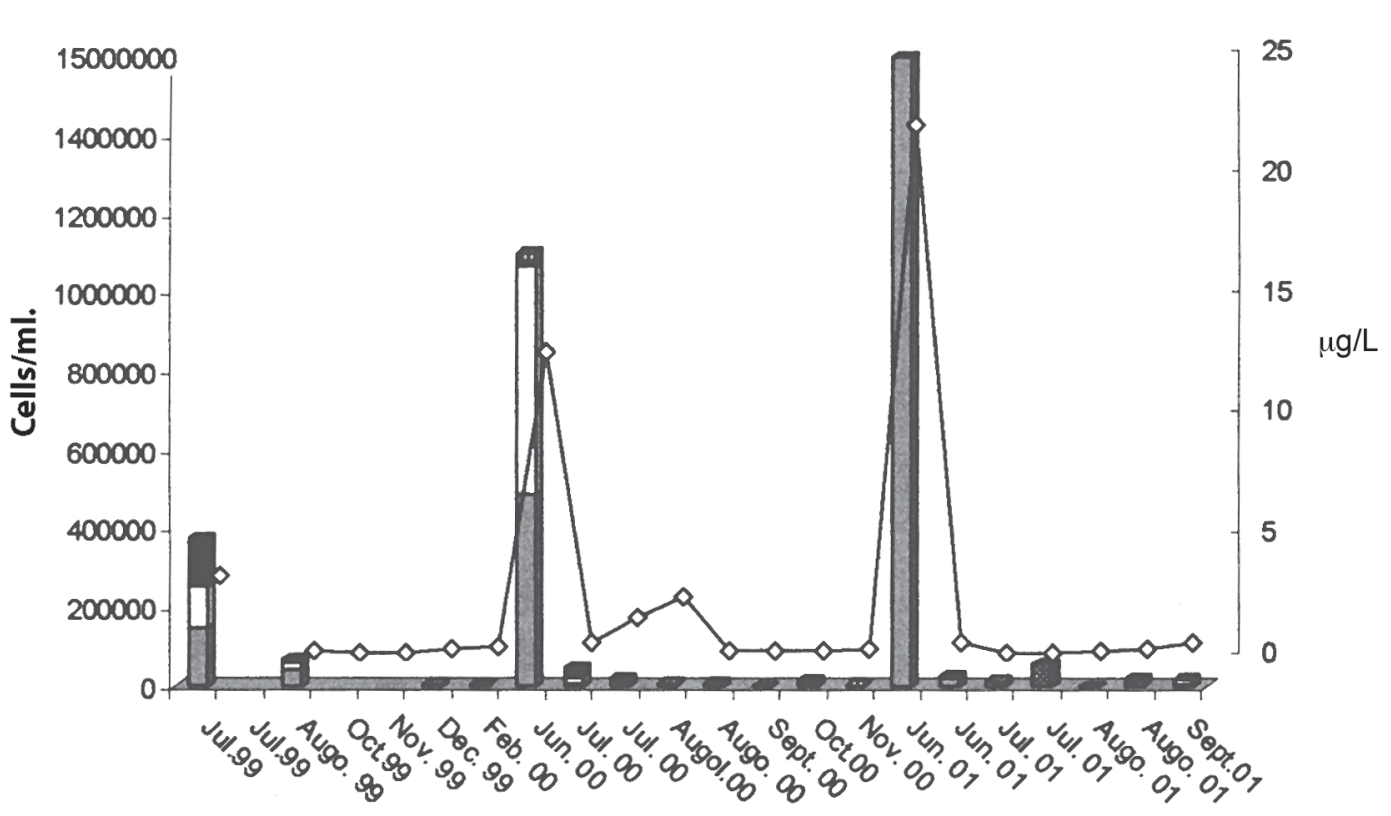

Figure 3. Seasonal variations of microcystin contents (ELISA analysis) compared with cyanobacterial biomass in natural waters from (A) Valdelacalzada and (B) Vitonogales. 
(b)

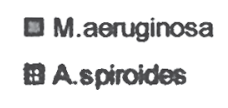

Ap. flos-aquae
口 Oscillatoria spp.

B. An. flos-aquae

A. issatchenkoi
A. aphanizomenoides A.inaequalis

A.solitaria

DA. circinalis

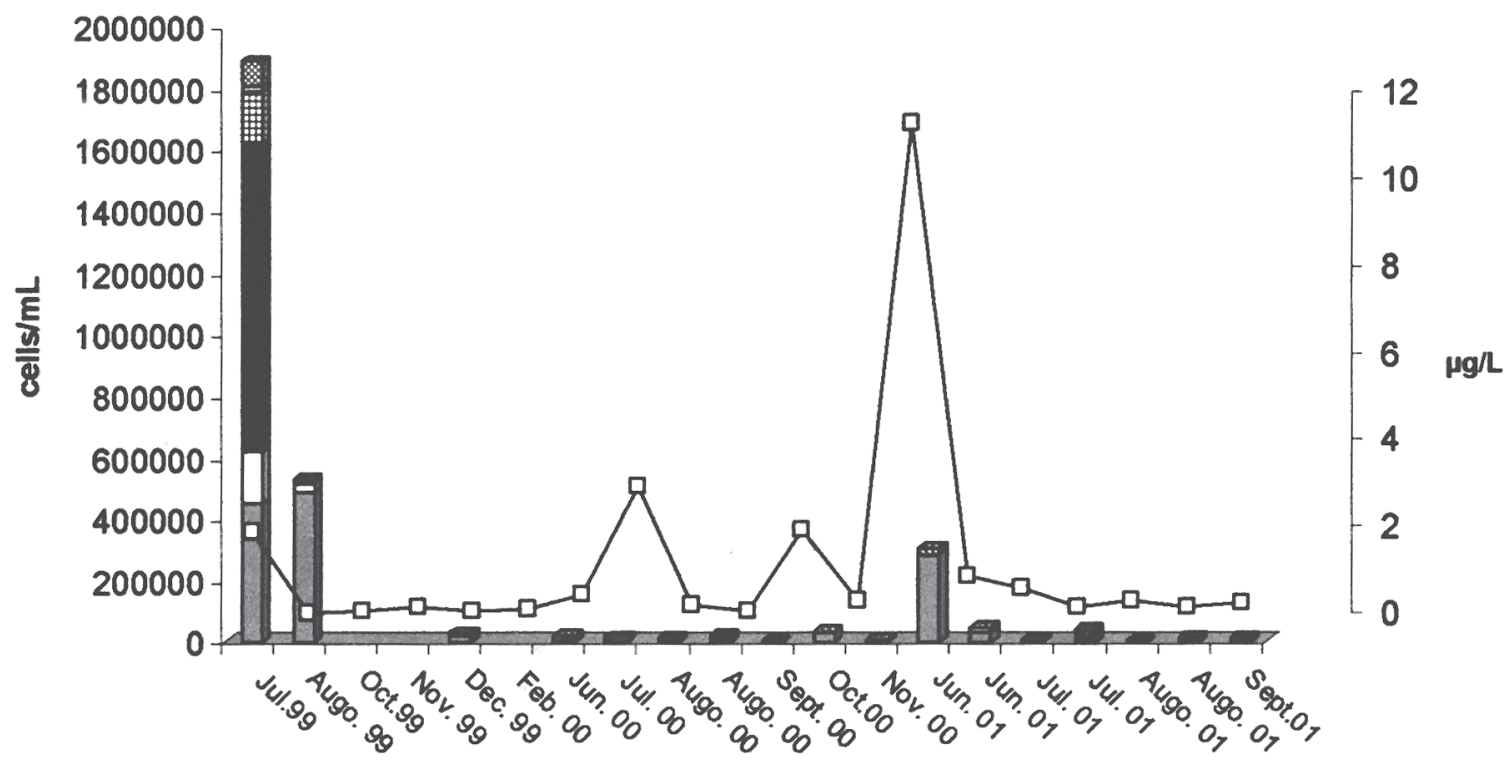

\section{Cyanobacterial strains}

Different strains of $M$. aeruginosa, Aphanizomenon flos-aquae and Anabaena spiroides were isolated from the natural bloom samples collected in July 1999 (Vitonogales) and in June, October, and November 2000 (Vitonogales and Valdelacalzada) (Table I). A screen for mcyst content performed by ELISA on freeze-dried cells of these strains grown in Z8 medium showed that only three strains of $M$. aeruginosa contained levels higher than $0.1 \mu \mathrm{g}$ mcyst-LR equivalent $\cdot \mathrm{L}^{-1}$, which is the detection limit of ELISA assay. Consequently, the real percentage of toxic $M$. aeruginosa isolated strains was $33 \%$.

Toxin determination in these three strains was measured by ELISA throughout the period of cultures growth and the cell quota was calculated (Fig. 4). While ISACYA 2C (from Vitonogales 1999) achieved the maximum level of toxin content per cell in five days of culture (341 fg mcyst-LR equiv $\cdot$ cell $^{-1}$ ), ISACYA 13 (from Valdelacalzada, 2000) reached the highest level of toxin per cell at day 19 of the growth period $(300 \mathrm{fg}$ mcyst-LR equivalent.cell-1). ISACYA 10A (from Vitogonales 1999) showed an extremely low level of mcyst per cell throughout the period of culture growth $(\leq 1 \mathrm{fg}$ mcyst-LR equivalent $\cdot$ cell $^{-1}$ ) (data not shown in Figure $4)$. The average of cell quota $(x)$ was not significantly different in ISACYA $2 \mathrm{C}$ and ISACYA $13\left(x\right.$ ISACYA $2 \mathrm{C}=124.3 \mathrm{fg} \cdot \mathrm{cell}^{-1}$ and $x$ ISACYA $13=141 \mathrm{fg} \cdot \mathrm{cell}^{-1}, \mathrm{p}=$ $0.754)$.

HPLC/UV analysis of the extracts from these strains was carried out in order to confirm the results obtained by ELISA and to determine the toxin profile of each strain (Fig. 5). Chromatograms of ISACYA 13 revealed the presence of mcyst-RR, mcystLR and mcyst-YR (Fig. 5A). The levels of mcyst detected (average of triplicates) were $164 \mu \mathrm{g} \cdot 100 \mathrm{mg}$ dry cell ${ }^{-1}$ of mcyst-RR, 40 $\mu \mathrm{g} \cdot 100 \mathrm{mg}$ dry cell ${ }^{-1}$ of mcyst-LR and 8.2 $\mu \mathrm{g} \cdot 100 \mathrm{mg}$ dry cell ${ }^{-1}$ of mcyst-YR. The analysis of ISACYA 2C (Fig. 5B) revealed a similar toxin profile with mcyst-RR being the dominant toxin $(300 \mu \mathrm{g} \cdot 100 \mathrm{mg}$ dry cell $\left.^{-1}\right)$ followed by mcyst-LR $(110 \mu \mathrm{g} \cdot 100$ mg dry cell $\left.{ }^{-1}\right)$ and by mcyst-YR $(73 \mu \mathrm{g} \cdot 100$ $\mathrm{mg}$ dry cell $\left.^{-1}\right)$. On the other hand the extracts of ISACYA $10 \mathrm{~A}$ did not show any 
detectable peak corresponding to mcyst-LR or mcyst-YR, but one peak was observed with a retention time identical to mcyst-RR standard (Fig. 5C). Moreover, spiking the extract with the particular standard, we could identify mcyst-RR and the toxin content obtained from comparison of peak areas was $0.75 \mu \mathrm{g}$ toxin $\cdot \mathrm{mL}^{-1}$ culture.

TABLE I

Cyanobacterial strains isolated from the natural bloom samples collected in July 1999 (Vitonogales) and in June, October, and November 2000 (Vitonogales and Valdelacalzada)

\begin{tabular}{|c|c|c|c|}
\hline Strain & Species & Origin & Mcyst (ELISA) mg/L \\
\hline ISACYA $2 \mathrm{C}$ & M. aeruginosa & Vitogonales (July 99) & 1.74 \\
\hline ISACYA 6A & M. aeruginosa & Vitogonales (July 99) & $\mathrm{ND}^{\mathrm{a}}$ \\
\hline ISACYA 9B & M. aeruginosa & Vitogonales (July 99) & ND \\
\hline ISACYA $10 \mathrm{~A}$ & M. aeruginosa & Vitogonales (July 99) & 0.12 \\
\hline ISACYA $1 \mathrm{~A}$ & A. spiroides & Vitogonales (July 99) & ND \\
\hline ISACYA 3A & A. spiroides & Vitogonales (July 99) & ND \\
\hline ISACYA 4A & A. flos-aquae & Vitogonales (July 99) & ND \\
\hline ISACYA 7A & A. flos-aquae & Vitogonales (July 99) & ND \\
\hline ISACYA $11 \mathrm{~A}$ & A. flos-aquae & Vitogonales (July 99) & ND \\
\hline ISACYA 12 & M. aeruginosa & Valdelacalzada (June 2000) & ND \\
\hline ISACYA 13 & M. aeruginosa & Valdelacalzada (June 2000) & 1.56 \\
\hline ISACYA 14 & M. aeruginosa & Vitogonales (Oct. 2000) & ND \\
\hline ISACYA 15 & M. aeruginosa & Vitogonales (Nov. 2000) & ND \\
\hline ISACYA $16 A$ & M. aeruginosa & Vitogonales (Nov. 2000) & ND \\
\hline
\end{tabular}

a ND: Not Detected

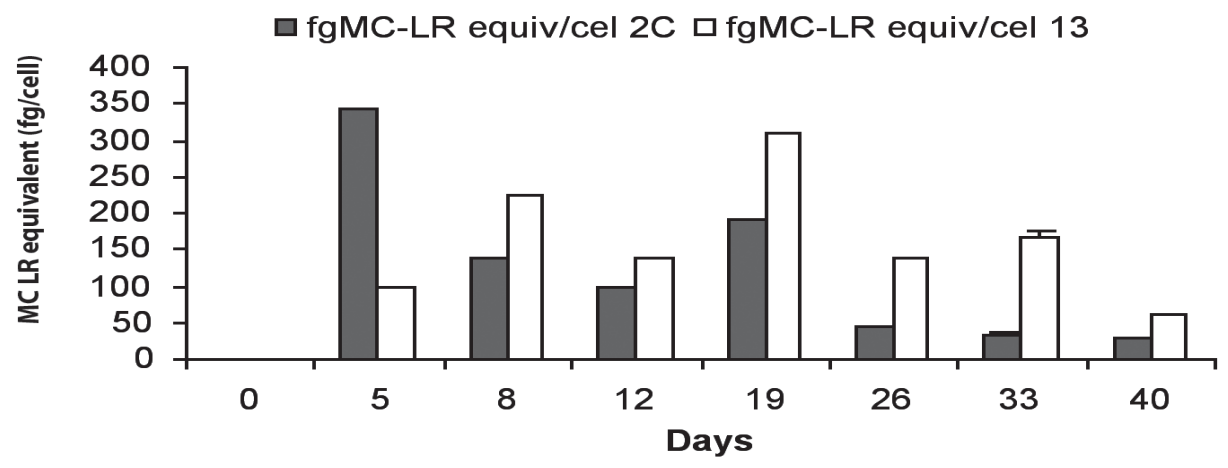

Figure 4. fgMC-LR equiv/cel average of the triplicate of Microcystis aeruginosa ISACYA 13 and ISACYA $2 \mathrm{C}$ strains. 


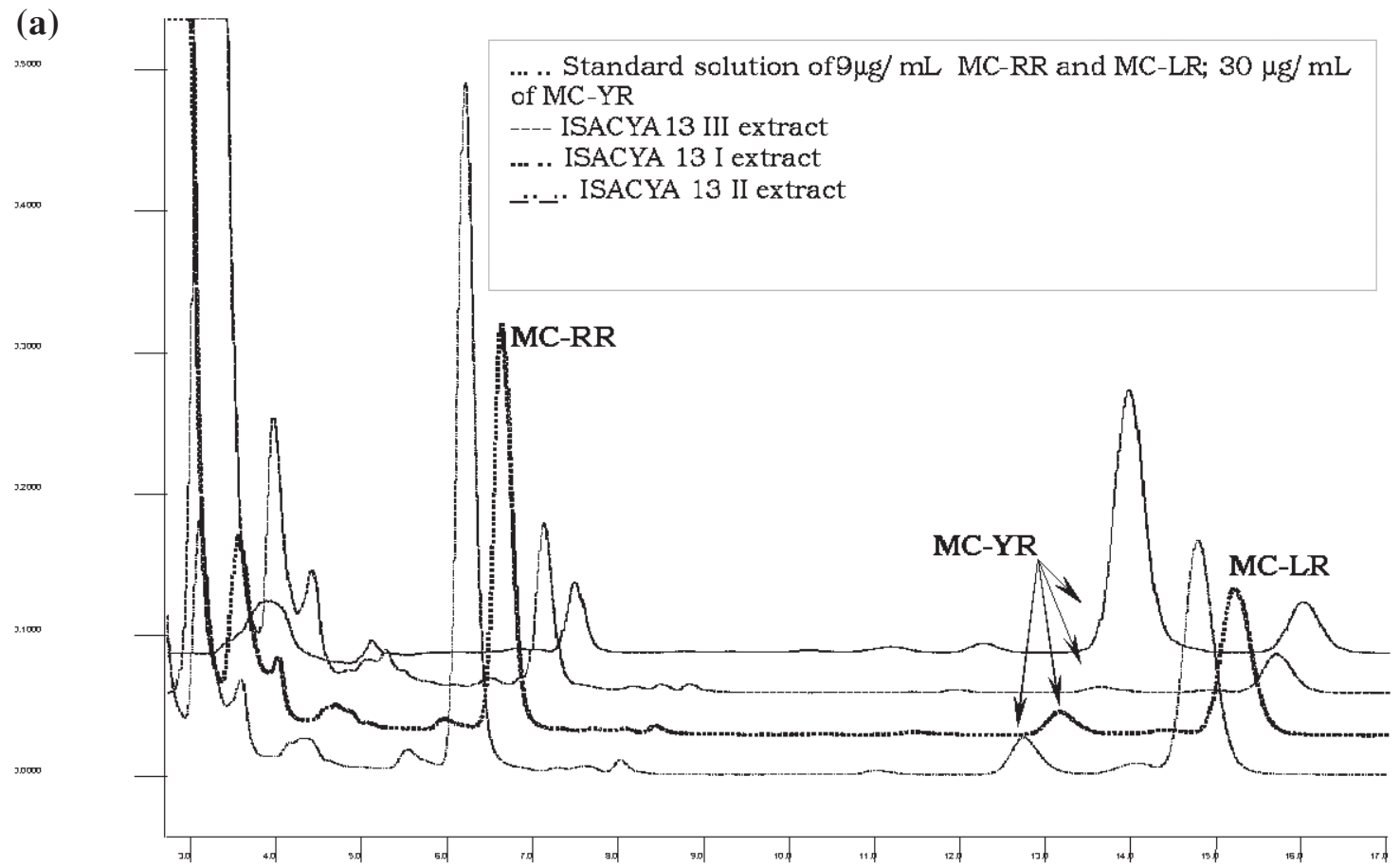

(b)

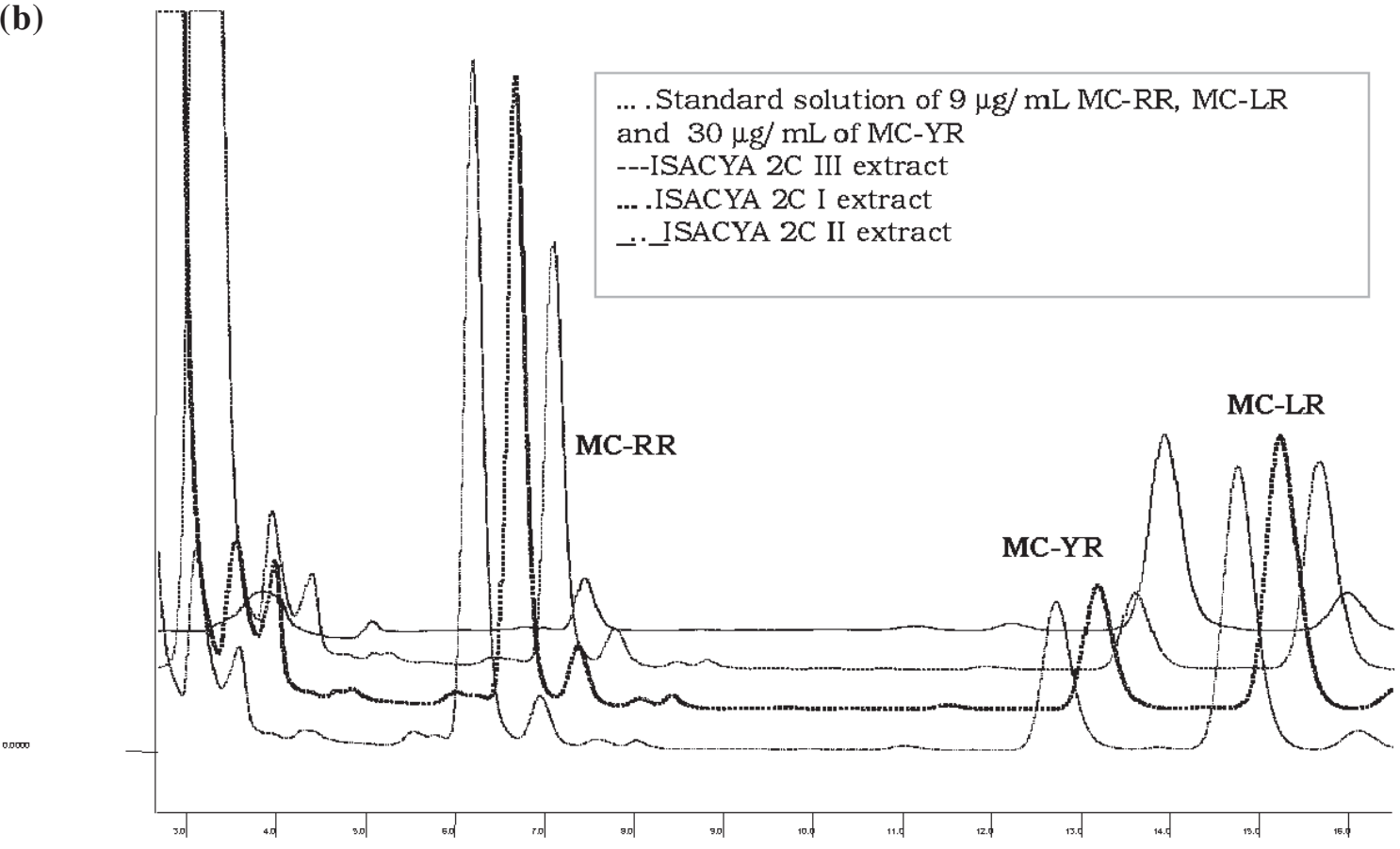

Figure 5. Chromatograms of the extracts of: (a) the ISACYA 13A strain in culture (in triplicate) and the standard solution of MC-RR, MC-LR and MC-YR.; (b) of ISACYA 2C strain (in triplicate) in culture and the standard solution of MC-RR, MC-LR and MC-YR; (c) of ISACYA 10 strain in culture, the extract spiked with a standard solution of $5 \mu \mathrm{g} / \mathrm{mL}$, and the standard solution of MCRR, MC-LR and MC-YR (5 $\mu \mathrm{g} / \mathrm{mL})$. 


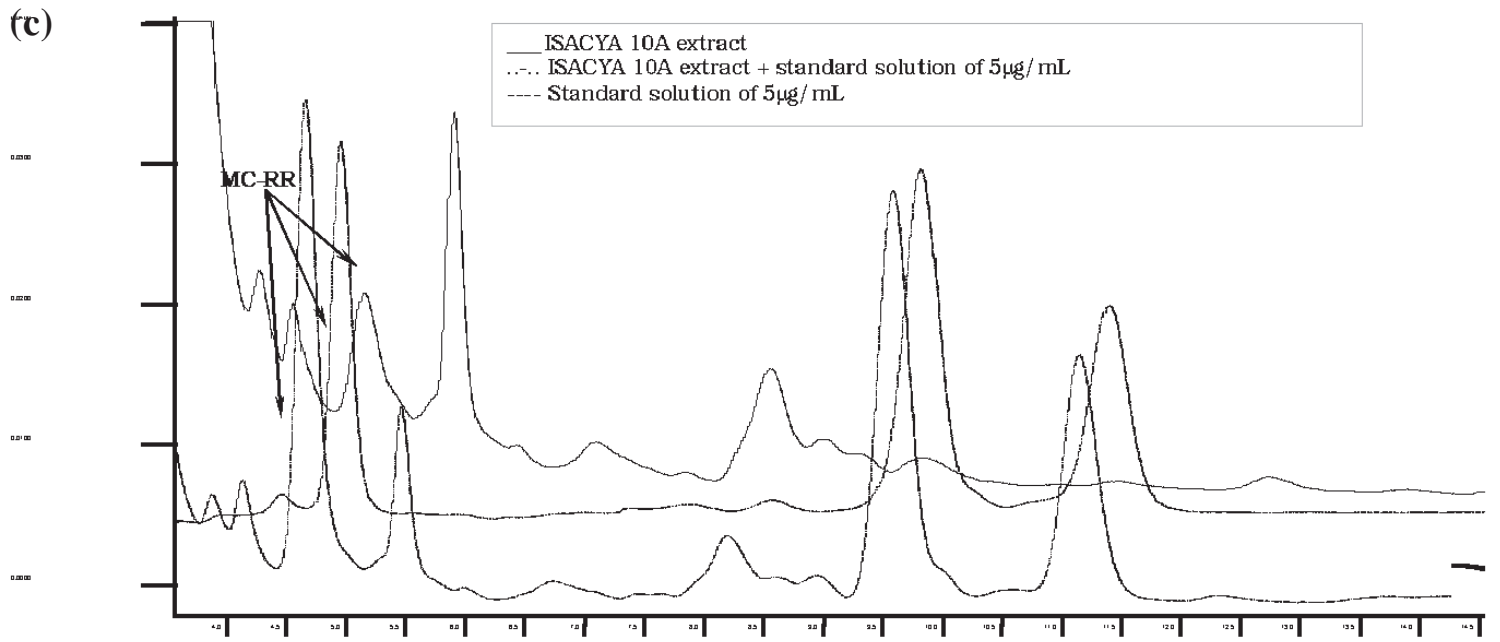

\section{DISCUSSION}

The first conclusion from the results presented here is that cyanobacterial blooms are frequent phenomena in the Spanish portion of the Guadiana River, occurring not only during summer periods, but also in colder months (Fig. 2).

It seems that these mass proliferations do not spread extensively throughout the entire river's course between Mérida and Badajoz. Instead, the cyanobacteria communities differed significantly, both qualitatively and quantitatively, among the different locations sampled and the blooms tend to form especially in the slow-flowing parts of the river. In fact, sudden changes in phytoplankton density and composition depending on temporal and spatial distribution of the collected samples were observed both within and between sampling sites. This fact could be explained by the ability of cyanobacteria to change their concentration and position in the water bodies within very short time (only a few hours) (Codd et al. 1999). Moreover, the relative availability of resources in the aquatic environment may play a major role in structuring phytoplankton communities (Rocha et al. 2002). This variability demands careful attention in establishing the correct sampling strategy for the truthful assessment of risks associated with cyanobacteria proliferations.
On the other hand, in two shallow and slow-flowing sites, Valdelacalzada and Vitonogales, located more than 10 miles apart from each other, blooms composed by the same dominant species formed simultaneously on several occasions (1999 and 2001), suggesting a common origin for these occurrences and a rapid dissemination of the bloom-forming species from one site to another. Although cyanobacterial blooms were not detected in Barbaño and Pescadores, the regular presence of Microcystis, Oscillatoria, Aphanizomenon, and Anabaena in these two well-streamed river sites suggests the possibility for these cyanobacteria to pass through these regions and travel along the river course. Bloomforming species will then proliferate in the slow-flowing river sites after encountering the most favourable conditions to grow.

The majority of cyanobacteria comprising the summer blooms occurring in the Guadiana River throughout its downstream course in Portugal (Vasconcelos 1994; Pereira et al. 1999; Rocha et al. 2002) were the same potential toxin producers found here (Microcystis aeruginosa, Aphanizomenon spp. and Anabaena spp.) and their presence has been related to the production of hepatotoxins and to fish mortality in that region (Vasconcelos 1993). Taking into consideration the results obtained in this report, it can be thought that at least some of the blooms observed in the Portuguese 
portion of the river may have their origin in Spain.

Blooms detected in the Valdelacalzada and Vitogonales sites were either monospecific or composed of several codominant species. The toxin content of the natural cyanobacteria blooms collected in both points (ELISA assay) showed a temporal variation with the highest level detected in July 1999, June 2000, and 2001. Moreover, marked differences in toxicity were observed among the different cyanobacterial strains isolated during the bloom periods and the simultaneous cooccurrence of both toxic and non toxic strains of same species ( $M$. aeruginosa) in the same bloom was confirmed (eg. the toxic ISACYA 2C and the non-toxic ISACYA 6A isolated from the bloom that occurred at Vitogonales in July 1999, or the toxic ISACYA 13 and the non-toxic ISACYA 12 isolated from the bloom that occurred in Valdelacalzada, June 2000). Moreover, HPLC-UV analysis revealed different toxin profiles among the toxic strains of $M$. aeruginosa isolated from the natural bloom samples. Two of the strains tested (ISACYA 2C and ISACYA 13) contained MC-RR, MC-YR, and MC-LR, although the contents varied among them. MC-RR was dominant; MC-LR was present in lower amounts and was finally MC-YR present in trace levels. The predominance of MC-RR was also demonstrated in cultures of different strains of $M$. aeruginosa isolated from several Japanese lakes (Shirai et al. 1991) and from water blooms detected in Moroccan reservoirs (Oudra et al. 2001).

The cell quota (fentogram/cell) also varied within the same strain during culture growth. The highest concentration of toxins by $M$. aeruginosa ISACYA 13 strain was reached at the beginning of the mid-log growth phase (19 days). M. aeruginosa ISACYA $2 \mathrm{C}$ reached maximum toxin production in 5 days of culture, just at the end of the lag growth phase, and in the beginning of the exponential growth phase. Considering these results, it could be affirmed that the toxicity of toxic Microcystis cells is variable and dependent upon the strains used and the culture conditions. Quantitative and qualitative variations in the microcystins present are most frequently found among different strains of Microcystis (Sivonen and Jones 1999). Moreover, many laboratory studies with pure cultured strains have found that growth and environmental factors can induce changes in toxicity and toxin concentration of a particular strain (Sivonen and Jones 1999).

Toxic variations, inter- and intra- strains of cyanobacteria, seem to be a common feature in natural blooms (Scott 1986; Shirai et al. 1991; Sivonen and Jones 1999). In this study, the wide range of toxicity observed in natural water samples (by ELISA analysis) and the establishment of isolated cyanobacteria cultures and their toxic profiles showed evidence of the complexity of the bloom communities, which can be formed by a cocktail of cyanobacteria simultaneously producing different types of toxins in different quantities and at different rates along the growth cycle, with some strains being nontoxigenic. These characteristics support the unpredictable nature of the blooms with respect to the overall toxicity occurring in the natural reservoir.

\section{CONCLUSIONS}

Taking into consideration the results obtained in this report, we conclude that: i) broad and sudden variations in the phytoplankton density, depending on the spatial distribution of the sampling sites, make the task of defining a good sampling strategy for the water bodies difficult; ii) at least some of the toxic blooms frequently observed in the Guadiana River along its course through the south of Portugal may have their origin upstream i.e. in the Spanish section of the river; and iii) toxic variations observed both inter- and intrastrains of cyanobacteria collected from the same bloom reflect the unpredictable nature of blooms with respect to the overall toxicity occurring in the natural water.

Further research is needed on this matter in order to establish the adequate proceedings to correctly assess risks of 
human exposure to toxic cyanobacteria. Considering that the Guadiana River is a natural border between Spain and Portugal, and bearing in mind that some of the toxic cyanobacterial waterblooms detected in the south of Portugal may have their origin in Spain, it would be important to review existing legislation concerning warnings and available information on toxic events in transnational waters (heavy metals, pesticides, radiation, etc) in order to include cyanotoxin in this category.

\section{ACKNOWLEDGEMENTS}

This work was mainly supported by a grant from the Andalusian Government (CTS358, II Plan Andaluz de Investigación), and I. Moreno was supported by a predoctoral fellowship from Institute Camões of Lisboa.

\section{REFERENCES}

ABED RMN, GARCÍA-PICHEL F, HERNÁNDEZMARINE M (2002) Polyphasic characterization of benthic, moderately halophilic, moderately thermophilic cyanobacteria with very thin trichomes and the proposal of Halomicronema excentricum gen. nov., sp nov. Archives of Microbiol 177: 361-370

AGUETE EC, GAGO-MARTÍNEZ A, LEAO JM, RODRÍGUEZ-VÁZQUEZ JA, MENÀRD C, LAWRENCE JF (2003) HPLC and HPCE analysis of microcystins RR, LR and YR present in cyanobacteia and water by using immunoaffinity wxtraction. Talanta 59: 697-705

BAKER P (1991) Urban Water Research Association of Australia. Identification of Common Noxious Cyanobacteria. Part I-Nostocales. Australian Centre for Water Treatment and Water Quality Research. Research Report No. 29, Melbourne and Metropolitan Board of Works

BAKER P (1992) Urban Water Research Association of Australia. Identification of Common Noxious Cyanobacteria. Part II-Chroococcales, Oscillatoriales. Australian Centre for Water Treatment and Water Quality Research. Research Report No. 46, Melbourne Water Corporation

BARCO M, RIVERA J, CAIXACH J (2002) Analysis of cyanobacterial hepatotoxins in water simples by microbore reversed-phase liquid chromatographyelectrospry ionisation mass spectrometry. J Chromatography A 959: 103-111

BARTRAM J, CARMICHAEL WW, CHORUS I, JONES G, SKULBERG O (1999) Introduction. In: CHORUS I, BARTRAM J (eds) Toxic Cyanobacteria in Water. A Guide to Their Public Health Consequences, Monitoring and Management, New York: E \& FN: pp: 1-14

BRITTAIN S, MOHAMED ZA, WANG J, LEHMANN VKB, CARMICHAEL WW, RINEHART KL (2000)
Isolation and characterization of microcystins from a River Nile strain of Oscillatoria tenuis Agardh ex Gomont. Toxicon 38: 1759-1771

CAMEÁN A, REINHARDT K, HUMMERT C, LUCKAS B (1997) Development of a method for the determination of hepatotoxic cyclopeptides (microcystins) from blue-green algae and its application to different matrices. J Veterinary Pharmacol and Therapeutics 20: 282-283

CODD GA, CHORUS I and BURCH M (1999) Design of Monitoring Programmes. In: Toxic Cyanobacteria in Water. In: CHORUS I, BARTRAM J (eds) A Guide to Their Public Health Consequences, Monitoring and Management. New York: E \& FN Spon. pp: 313-345

FASTNER J, ERHARD M, CARMICHAEL WW, SUN F, RINEHART KL, RÖNICKE H, CHORUS I (1999) Characterization and diversity of microcystins in natural blooms and strains of the genera Microcystis and Planktothrix from German freshwaters. Archives Hydrobiol 145: 147-163

FERREIRA FMB, FRANCO-SOLER JM, HIDALGO ML, FERNÁNDEZ-VILA P (2001) PSP toxins from Aphanizomenon flos-aquae (cyanobacteria) collected in the Crestuma-Lever Reservoir (Douro River, northern Portugal). Toxicon 39: 757-761

GAGO-MARTÍNEZ A, PIÑEIRO N, AGUETE EC, VAQUERO E, NOGUEIRAS M, LEAO JM, RODRÍGUEZ-VÁZQUEZ JA, DABEKZLOTORZYNSKA E (2003) Further improvements in the application of high-performance liquid chromatography, capillary electrophoresis and capillary electrochromatography to the analysis of algal toxins in the aquatic environment. J Chromatography A 992: $159-168$

GARCÍA C, PEREIRA P, VALLE L, LAGOS N (2003) Quantitation of diarrhetic shellfish poisoning toxins in Chilean Mussel using pyrenyldiazomethane as fluorescent labeling reagent. Biol Res 36. 171-183

GARCÍA-PICHEL F, PRINGAULT O (2001) Cyanobacteria track water in desert soils. Nature London, 413: 380-381

JOCHIMSEN EM, CARMICHAEL WW, AN J, CARDO DM, COOKSON ST, HOLMES CEM, ANTUNES BC, LIHO D, LYRA TM, BARRETO VST, AZEVEDO SMFO, JARVIS WR (1998) Liver Failure and Death After Exposure to Microcystins at a Hemodyalisis Center in Brazil. New England J of Med 338: 873-878

KOMAREK J, AGNOSTIDIS K (1986) Modern approach to the classification system of Cyanophites 2Chroococcales. Archives Hydrobioly/suppl. 73, Algol Stud 43: 157-226

KUIPER-GOODMAN T, FALCONER I, FITZGERALD J (1999) Human Health Aspects. In: CHORUS I, BARTRAM J (eds) Toxic Cyanobacteria in Water. A Guide to Their Public Health Consequences, Monitoring and Management. New York: E \& FN Spon pp: 113-153

LAGOS N, ONODERA H, ZAGATTO PA, ANDRINOLO D, AZEVEDO SM, OSHIMA Y (1999) The first evidence of paralityc shellfish toxins in the freshwater cyanobacterium Cylindrospermopsis raciborskii, isolated from Brazil. Toxicon 37: 1359-1373

LÓPEZ-RODAS V, COSTAS E (1997) Characterization of morphospecies and strains of Microcystis (Cyanobacteria) from natural populations and laboratory clones using cell probes (lectins and antibodies). J of Phycol 33: 446-454

NISHIWAKI-MATSUSHIMA R, OHTA T, NISHIWAKI S, SUGAWAMA M, KOHYAMA K, ISHIKAWA T, CARMICHAEL WW, FUJIKI H (1992) Liver tumor 
promotion by the cyanobacterial cyclic peptide toxin microcystin-LR. J Cancer Res Clinical Oncol 118 pp: 420-424

OUDRA B, LOUDIKI M, SBIYYAA B, MARTINS R, VASCONCELOS V, NAMIKOSHI N (2001) Isolation, characterization and quantification of microcystins (heptapeptides hepatotoxins) in Microcystis aeruginosa dominated bloom of LallacTakerkoust Lake-Reservoir (Morocco). Toxicon 39: 1375-1381

PEREIRA P, TAVARES MJ, VASCONCELOS V, FRANCA S (1999) Ocorrência de cianobactérias e microcistinas em aguas doces superficiais, nos anos de 1996-98, nas regiões do centro e sul de Portugal. In: Actas de la VI Reunión Ibérica sobre fitoplancton tóxico y biotoxinas. C.A.P.D.G. Junta de Andalucia. Spain. (Abstract in English). pp: 109-117

QUESADA A, NIEVA M, LEGANES F, UCHA A, MARTIN M, PROSPERI C, FERNÁNDEZVALIENTE E (1998) Acclimation of cyanobacterial communities in rice fields and response of nitrogenase activity to light regime. Microbial Ecol 35: 147-155

RIVAS M, GARCÍA C, LIBERONA JL, LAGOS N (2000) Biochemical characterization and inhibitory effects of dinophysistoxin-1, okadaic acid and microcystine LR on protein phosphatase 2 a purified from the mussel Mytilus chilensis. Biol Res 33:197-206

ROCHA C, GALVAO H, BARBOSA A (2002) Role of transient silicon limitation in the development of cyanobacteria blooms in the Guadiana estuary, southwestern Iberia. Marine Ecol Progress Series 228: 35-45

SCOTT WE (1986) Examination of toxic and non-toxic Microcystis aeruginosa in the field and in laboratory culture. In: STEYN PS, VLEGGAAR R (eds) Mycotoxins and Phycotoxins. Amsterdam: Elsevier. pp: 41-50

SHIRAI M, OHTAKE A, SANO T, MATSUMOTO S, SAKAMOTO T, SATO A, AIDA T, HARADA K,
SHIMADA T, SUZUKI M, NAKANO M (1991) Toxicity and toxins of natural blooms and isolated strains of Microcystis spp. (Cyanobacteria) and improved procedure for purification of cultures. Applied and Environmental Microbiol 57: 1241-1245

SIVONEN K, JONES G (1999) Cyanobacterial Toxins. In: CHORUS I, BARTRAM J (eds) Toxic Cyanobacteria in Water. A Guide to Their Public Health Consequences, Monitoring and Management. New York: E \& FN Spon. pp: 41-111

SKULBERG R, SKULBERG OM (1990) Forskning med algekulturer NIVAs kultursampling av alger. Norway: NIVA

UENO Y, NAGATA S, TSUTSUMI T, HASEGAWA A, WATANABE MF, PARK HD, CHEN GC, CHEN G, YU SZ (1996) Detection of Microcystins, a blue-green algal hepatotoxin, in drinking water sampled in Haimen and Fusui, endemic areas of primary liver cancer in China, by highly sensitive immunoassay. Carcinogenesis 17: 1317-1321

UTERMÖHL H (1958) Zur Vervollkommung der quantitative Phytoplankton-Metodik. Mitt. International Verein. Theor Angew Limnol 5 pp: 567-596

VASCONCELOS VM (1993) Toxicity of Cianobacteria in lakes of North and Central Portugal. Ecological implications. Verh. International Verein. Limnol 25 pp: 694-697

VASCONCELOS VM (1994) Toxic cyanobacteria (bluegreen algae) in Portuguese fresh waters. Archives Hydrobiol 130: 439-451

VASCONCELOS VM, SIVONEN K, EVANS WR, CARMICHAEL WW, NAMIKOSHI M (1996) Hepatotoxic microcystin diversity in cyanobacterial blooms collected in Portuguese freshwaters. Water Research 30: 2377-2384 